LA-UR- 92-889

(REVISED)
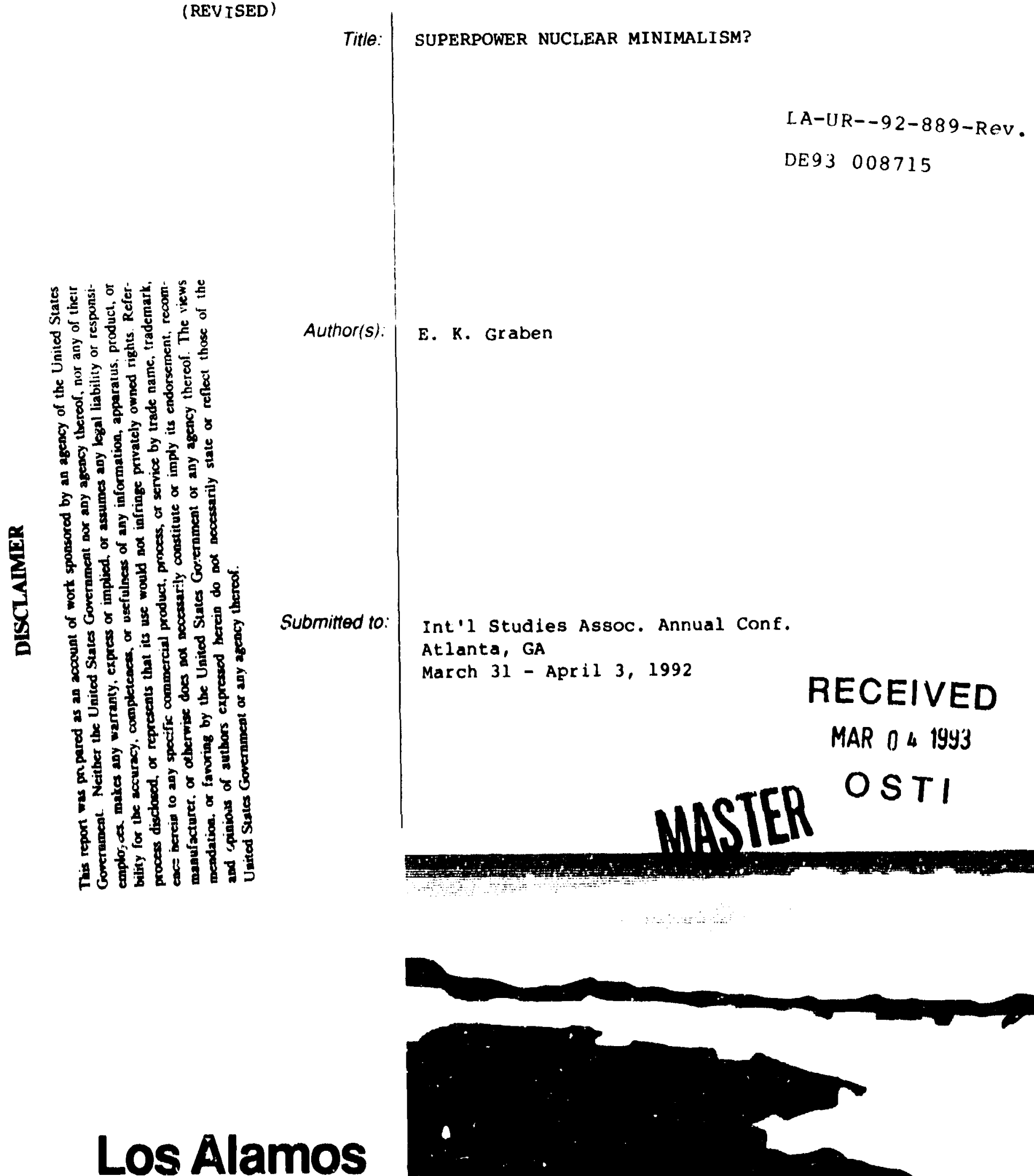

NATIONAL LABURATORY

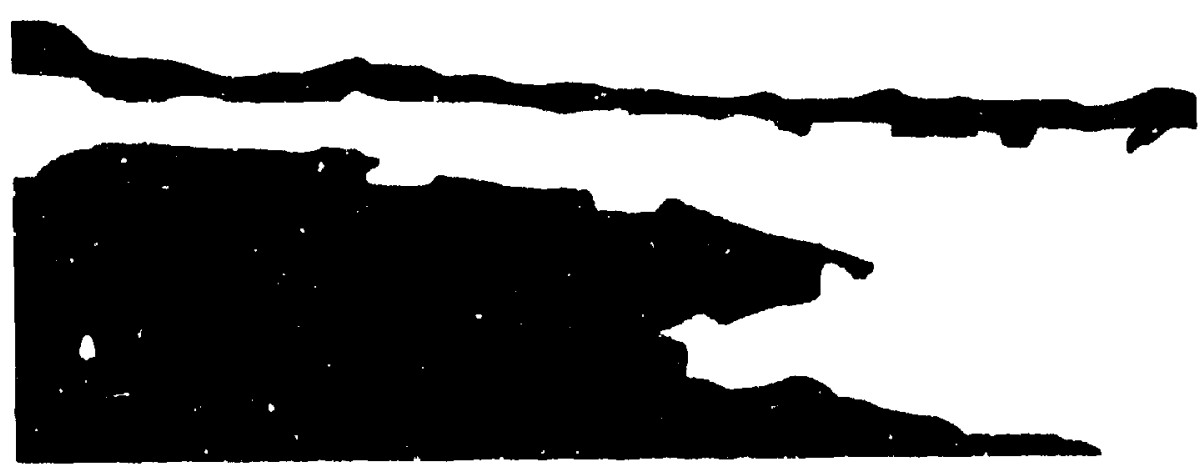

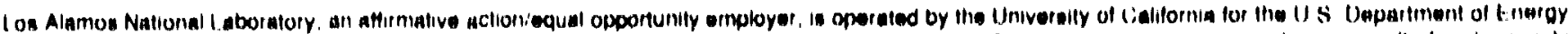

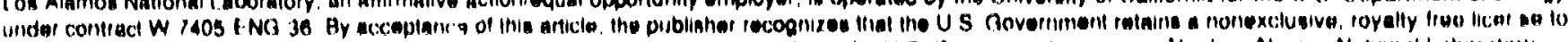

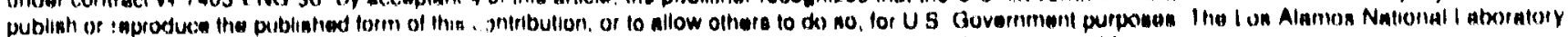
cequenis that the publisher identify this articin as woik pertermed under the evepices of the U $\mathbf{S}$ Department of Enargy 


\title{
Superpower Nuclear Minimalism in the Post-Cold War Era?
}

\author{
Eric K. Graben \\ Center for National Security Studies \\ Los Alamos National Laboratory
}

Submitted to Arms Conrrol

Revised July 1992

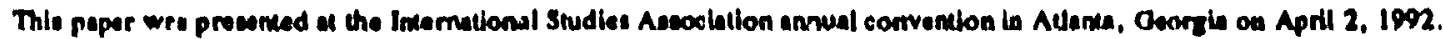

The suthor withes wo thent Robort Olower for his many uenNul vommenes on this paper.

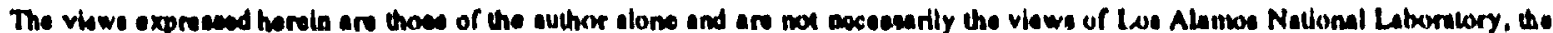

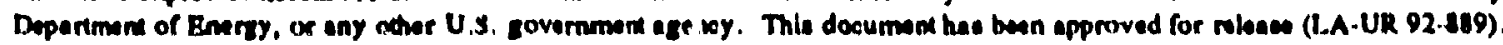




\section{Superpower Nuclear Minimalism in the Post-Cold War Era? \\ Eric $\boldsymbol{K}$. Graben}

During the Cold War, the United States and the Soviat Union competed in building weapors -- now it seems like America and Russia are competing to get rid of them the fastest. The lengthy process of formal arms control has been replacixd by exchanges of unilateral force reductions and one-and-a-half page Joint Understandings to be codified in much briefer treaties than ST.ART. Should superpower nuclear strategies change along with force postures? President Bush has yet to make a formal pronouncement on post-Cold War American nuclea' strategy, and it is uncertain if the Soviet/Russian coctrine of reasonable sufficiency formulated in the Onrbachev era actually heralds a change in strategy. Some of the provisions in the June 1992 Joint Understanding on Reductions in Offensive Strategic Weapons are compatible with a change in strategy. Whether such a change has actually occurred remains to be seen.

With the end of the Cold War and the breakup of the Soviet Union, the strategic elivironment has fundamentally changed, so it would seem logical to reexamine strategy as well. 
There are two main schools of nuclear strategic thought: a maximalist school, which ernphasizes counterforce superiority and nuclear war-fighting capability, and a MAD-plus school, which emphasizes survivability of an assured destruction capability along with the ability to deliver small, limited nuclear attacks in the event that conflict occurs. The MAD-plus strategy is the more logicai of the two strategies, because the maximalist strategy is based on an attempt to conventionalize nuclear weapons which is unrealistic.

Yet throughout the Cold War, both the United States and the Soviet Union adhered to the maximalist concept of deterrence. Both governments believed security was provided by preparing for a war with the other. Both state's military establishments believed that this required a nuclear war-fighting capability where nuclear weapons were treated as extremely destructive conventional weapons. Civilian leade', were unwilling to challenge the assumptions on which strategic doctrine was based. Even if a government had desired to reject the maximalist strategy and adopt the MAD-plus strategy, it would have been unsafe to do so unilaterally. Someone believing in the maximalist strategy is unlikely to find the MAD-plus strategy credible. Since deterrence is a subjective thing, one has to have a deterrent forie that the opponent, not oneself, considers a good deterrent. Therefore, if one side was maximalist, then the other side must be so as well for stable deterrence to obtain.

Now that the Cold War is over, it may be possible for America and Russia (or the CIS) to abandon their maximalist, war-fighting nucleas strategies and adopt the MAD-plus strategy. What makes this possible is the change in threat perception that has occurred with the end of the Cold War. Neither state considers the other a dire threat to itssecurity. If the MAD-plus strategy is adopted by both sides, future reductions in nuclear arsenals will be facilitated, the 
portion of the peace dividend from strategic forces can be maximized, and strategic stability will be enhanced in the event that future conflict arises.

The euphoria over the end of the Cold War might lead one to ask, why worry about nuclear strategy at all? Peihaps all we have to worry about is making sure old Soviet weapons do not get sold to the Third World? Russia, even on its own, vill remain at least a nuclear superpower, and either a new union of former Soviet republics or a united nuclear command in the CIS will certainly constitute a nuclear superpower. Nuclear weapons are not going to go away by themselves, and U.S.-Russian relations are unlikely to be as cordial as U.S.-British relations, so America still needs to deter the successor to the Soviet Union. This should be done as inoffensively as possible. If Russia is less threatened, it can devote more of its resources to developing a capitalist economic system and a democratic political system, which in tum enhances American security. There is a chance that a fascist or otherwise hostiie government could arise in the former Soviet Union. Historically, one of the ways dictators have gained popular support is by claiming a need to defend against an external threat. Adopting a MADplus strategy will make the Unitod States less threatening to the CIS and help minimize the chance of a hostile regime arising in the former Soviet Union. It is important to note though, that the United States should adopt a MAD-plus nuclear strategy only if the former Soviet Union does as well, because a MAD-plus strategy and force posture cannot reliably deter a maximalist opponent as will be discussed below. 


\section{The Two Nuciear Strategies}

Two main approaches to nuclear strategy have dominated the discussion of nuclear deterrence since the dawn of the nuclear age. The first is the maximalist strategy, also known as the countervailing strategy, which treats nuclear war in much the same way as conventional war. The second is the MAD-plus strategy, which is based on the realization that nuclear weapons are fundamentally different from conventional weapons because of their destructiveness. Both strategies seek to achieye the same goals, and both ultimately rely on the assured atility to destroy an opponent state as a functioning society, hereafter referred to as an assured destruction capability. They differ on what is required to achieve, stable deterrence beyond the assured destruction capability. The goals of both strategies are as follows,

1. The deterrence of the use of nuclear weapons

2. The termination of nuclear war as quickly as possible and on terms as favorable as possible should war occur

3. The continued existence and political independence of the United States and its vital allies (the West European states and Japan)

\section{ASSURED DESTRUCTION AND THE MINIMALIST SCHOOL OF DETERRENCE.}

Both the maximalist and MAD-plus deterrent strategies are suphisticated revisions of the simpler ninimalist nuclear strategy, so this strategy will be outlined first. All nuclear strategies are based on certain assumptions about the nature of nuclear war. The minimalist assumptions are: (1) No political goal is worth the price of receiving a strategic nuclear attack. (2) It is impossible to limit the damage from a massive nuclear attack. (3) Escalation to massive nuclear exchanges from a lesser conflict is so likely that it must be treated as a certainty; therefore a nuclear war cannol be fought. The implication of these assumptions is what McGeorge Bundy 
has called 'existential deterrence': the prospect of having one's country made into a smoking, radiating ruin is enough to deter anyone from ever using nuclear weapons under any circumstances. Therefore, any aggression should be deterred simply by the existence of an opponent's nuclear weapons.'

'Hard core' minimalists would prescribe that America needs only the possibility, not necessarily the certainty, of just a few (perhaps 10) nuclear weapons surviving an attack to have a secure deterrent. More prudent minimalists require the existence of an assured destruction capability, that is, a nuclear force that can survive an opponent's strongest attack and still inflict unacceptable damage on the opponent. Such a capability is often referred to as the McNamara criteria. According to the McNamara criteria, 'unacceptable damage' is the destruction of 20 to 30 percent of the population of the former Soviet Union and 50 to 70 percent of its industrial capability. ${ }^{2}$ To ensure such destruction, the United States needs 200 to 400 survivable equivalent megatons (EMT) worth of nuclear warheads. ${ }^{3}$

Strategic stability is achieved when both sides have an assured destruction capability producing a situation of mutual assured destruction or MAD. Since reither side can prevent its own destruction by striking first, neither has an incentive to attack, 30 the situation is stable. Beyond the Mcldamara criteria, further weapons are unnecessary and can even be harniful. The massive deployment of hand-target-kill capable weapons might lead one to believe that a firststrike can meaningfully limit damage when, in fact, it cunnot. This in lum might lead one to believe nuclear wars cm:- be safely fought thus weakening deterrence.

Very few, if any, 'real people' are minimalists. The assumption that any conflict will escalate to massive nuclear attacks on cities was proven false very early in the nuclear age by 
the Korean War. Since the possibility of escalation to massive nuclear exchanges would not deter all attacks, lesser options were deemed necessary. During the Kennedy administration, the addition of limited options to the assured destruction capability was formalized in the doctrine of flexible response, which was NATO's strategy for dealing with Soviet numerical conventional superiority. According to the doctrine of flexible response, NATO might have to resort to the use of nuclear weapons to halt a Soviet advance into Western Europe. It was necessary to have some nuclear options besides a massive attack on Soviet cities which would lead to a mutually devastating response in kind. During the Nixon, Ford, and Carter administrations, flexible response was expanded intn the countervailing strategy, which called for nuclear options ranging from the use of a few nuclear artillery shells to massive scrategic attacks on the Soviet swategic arsenal. The rationale for LNOs was developed in response to the threat of a Soviet invasion of Western Europe, which is no longer at all. likely, but the rationale for $\mathrm{LNO}$ applies to any conflict that could arise between nuclear powers, not just one centered in Europe.

MAXIMALISM." The maximalist or countervailing strategy is based on some different assumptions from the minimalist school. The maximalist agrees with the minimalist that no political goal is worth the price of having one's cities destroyed in a massive countervalue attack, hut because of this, the maximalist assumes that it is impossible to credibly threaten to launch such an attack except as a response in kind. The maximalist strategy further assumes that it is likely that nuclear war can be kept limited and escalation to unacceptable levels can be prevented, because it is illogical to escalate to full-scale countervalue exchanges. Some, but not 
all, maximalists also believe that it is possible to meaningfully limit damage to one's own country by using counterforce attacks on an opponent's nuclear arsenal.

The assumption that escalation can probably be controlled inplies that the United States needs to be able to fight an extended nuclear war at any level of conflict. Th United States may not be able to win such a war, but it should certainly be able to avoid losing it, and it must make an opponent sure that it cannot win. In order to fight at high levels of nuclear war, the United States must be able to attack the nuslear arsenal of its opponent with what are called counterforce attacks. It must also minimize the vulnerability of its own arsenal to such an attack. Therefore, highly survivable counterforce capability is necessary for deterrence. An opponent must not be able to get into a 'better' strategic position by initiating a counterforce exchange," io the United States needs an arsenal such that the U.S.-Russian/CIS ratio of counterforcecapable warheads is not significantly worse after a counterforce exchange than it was to begin with, and such that all of the military targets in Russia or the CIS can be covered after absorbing a counterforce first strike. Such an ability would allow the United States to credibly threaten to fight at any level of conflict without having to resort to mutually-suicióal attacks on cities.

The ultimate deterrent for the maximalist school ir the threat to destroy the leadership of its opponent, not the threat to destruy cities. One reason for this change in the definition of 'assured destuction' from the minimalist definition is that it is immoral to attack civilians under the Christian Just War tradition. Another reason is that deterrence is ultimately assured by the ability to destroy what an opponent values most. The minimalist school assumes that the Soviet leadership, or now Russia or the CIS, values its population and industry the most. The maximalist schonl also believes that Soviet or Russian leaders value their population and 
industry, but what they value most is themselves. So the ultimate deterrent is the ability to destroy Russian leaders. Because of the immorality of targeting civilians, the maximalist believes no American leader would ever be willing to execute such a strike and could not credibly threaten to do so.

Many leadership targets in the former Soviet Union are based in hardened bunkers, and modem ICBMs, which make up a large part of superpower strategic arsenals, particularly in the CIS, are based in hardened silos, so counterforce capability is usually equated with hard-targetkill capability. Currently the CIS has about 1,400 missile silos and perhaps thousands of leadership bunkers. For all practical purposes under START and the June 1992 Joint Understanding, the maximalist would advocate deploying as many survivable, hard-target-kill capable weapons as possible to be able to cover the target base after absorbing a first strike. One of the last American Cold War plans for nuclear war listed 50,000 targets and required the ability to 'it 5,400 targets with about 3,800 weapons after absorbing a first strike. ${ }^{\top}$ The number of hard targets within this total could go down as ICBMs are dismantled under START and the future treaty based on the Joint Understanding, but the number of survivable warheads should still be maximized to obtain the most favorable post-exchange nuclear-balance.

The maximalist school seeks to 'conventionalize' nuclear weapons using them only to attack an opponent's leadership and military targets, which is compitible with jus in bello ethics and which seeks to make it possible to rationally use strategic nuclear weapons on a large scale." This means the maximalist seeks to find a military utility for strategic weapons, where 'military utility' is defined as being able to contribute to vanquishing an opponent in combat. It is hoped that massive civilian casualties and economic loss can be avoided either by limiting the conflict 
to military targets by implicit mutual agreement with the opponent or, depending on the strategist, by actually destroying, with counterforce strikes, an opponent's ability to attack cities. The primary difference between the MAD-plus school and the maximalist school is that MADplus considers such conventionalization impossible because of the immense destructive power of strategic weapons.

THE MAD-FLUS SCHOOL OF DETERRENCE.' The MAD-plus strategy assumes that the collateral damage to civilians from any large-scale use of nuclear weapons, regardless of intended target, would constitute assured destruction and would be tco great a price to pay for any political goal. It is also assumed that the likelihood of escalation from a low level of nuclear conflict to countervalue exchan,es, while not certain, is likely, especially if large attacks are utilized. The MAD-plus strategist agrees with the maximalist that the threat to launch a massive countervalue sirike is not a credible response to most provocations, so some LNO capability is necessary. To meet the two goals of avoiding escalation to catastrophic levels of conflict and maintain credibility of response, the MAD-plus school advocates the threat to use very small LNOs. As Thomas Schelling has pointed out, the sole purpose of such LNOs is to demonstrate a resolve to continue to fight unless an equitable cessation of hostilities is achieved. ${ }^{10}$ Because of the destructiveness of strategic weapons and the size and survivability of superpower arsenals, they cannot be used to achieve military victory.

A typical LNO for the MAD-plus school would involve using a handful of weapons to destroy a fraction of an opponent's oil refining capacity (a few large, soft refineries). such an attack would demonstrate that all of the capacity could be destroyed. but would also demonstrate that the remainder of the refineries could be preserved by an cessation of hostilities, giving the 
oppunent an incentive to terminate hestilities. The MAD-plus school of Jeterrence would prescribe 2 deterrent force capable of fielding the McNamara criteria of 200 to 400 survivable EMT after no more than a couple of hundred weapons have been allocated for use in LNOs.

Why is MAD-Plus the Better Strategy?

Of the two strategies, the MAD-plus strategy is objectively the logical one. The attempt to conventionalize nuclear weapons in the maximalist strategy is impossible and produces false or at least questionable assumptions. Deterrence is, however, a subjective thing, not an objective thing. A good deterrent is determined in the eyes of the person to be deterred, like beauty is in the eye of the beholder. Therefore, if one's opponent believes in an illogical strategy, it may be necessary to adopt what one knows is an illogical strategy to deter the opponent.

The maximalist straiegy assumes that massive counterforce strikes are 'limited', which means that they produce significantly fewer civilian casualties than countervalue attacks and aiso that targeting leadership instead of civilians in order to provide the ultimate deterrent :vill significantly reduce civilian casualties. No one will know for sure what the casualties from a nuslear war would be because of a fortunate lack of empirical evidence, but the best estimates of experts suggest that massive counterforce attacks could produce up to tens of millions of casualties. The Office of Technology Assessment estimated in 1979 that 20 million Americans and 10 million Soviets could oie from prompt effects alone in a Soviet-initiated counterforce exchange compared to the 90-180 million American and 60-100 million Soviet casualties respectively from a countervalue exchange." Barbara Levi, Frank von Hippel, and Wili . . 
Dougherty have revised the OrA estimate using a more sophisticated computer model. They estimate that counterforce strikes could produce 13-34 million American deaths and 12-27 million Soviet deaths compared to 25-60 million American casualties and 95-77 million Soviet deaths from a countervalue exchange. ${ }^{12}$ Since most Soviet leadership targets probably are located near or in cities, counterleadership attacks would resemble countervalue attacks in the casualties they produce. Even if most leadership targets are not in or near cities, they are in hardened bunkers similar to ICBM silos, so the collateral damage from a counterleadership attack would at least resemble the damage from a counterforce attack.

The question is, what level of destruction will deter a potential adversary? The Soviet Union suffered about 20 million casualties in WWU spread out over about 4 years. Since it survived, this number of casualties might not be sufficient for assured destruction. It is fairly certain that neither superpower would initiate an exchange leading to such casualties for political gain such as conquering new territory or winning a proxy conflict in the third world, since no such gain would be worth this cost. The Soviet Union did not initiate hostilities in 1941. It is plausible though, that a state would be willing to incur such casualties for a vital interest like national survival. No one claims that the Soviet Union would have heen better off by surrendering to Adolph Hitler. A lesser but still vital interest like the survival of America's European allies or access to vital natural resources like Middle Eastern oil may or may not be worth the cost of such casualties depending on the person making the decision. Whether a state could incur such casualties in a few days and survive the ensuing dislocation as a functioning state is debatable. Even if a state could and would accept 20 million casualties, Levi, von 
Hippel, and Dougherty, estimate that counterforce casualties could be 65 percent higher than this.

While it may be uncertain whether or not the casualties from a counterforce exchange would be enough to deter any aggression, it is more certain that such exchanges would produce no militarify useful result that would vanquish an opponent in the traditional military definition of victory. Since the early 1960s, neither side has had any chance of being able to prevent its opponent from launching a countervalue second strike by launching a counterforce first strike. It is unlikely that, even with the end of the Cold War, Ameriva and Russia (or the CIS) will disarm themselves to the point of giving the other a damage-limiting, first-strike capability. Thus, if one state launched a 'limited' counterforce first strike, it would not be able to ensure the safety of its own civilians, it would not enhance the credibility of a threatened follow-on countervalue strike, and it would have greatly angered its opponent by killing tens of millions of its citizens. The opporent might not even be able to tell that the strike was a 'limited strike'.

Mascive counterforce attacks could demonstrate a resolve to continue to fight, which could serve the political goal of termination of hostilities on favorable terms. As Thomas Schelling has pointed out, the purpose of limited nuclear attacks is to demonstrate such resolve by demonstrating the 'vitalness' of a particular interest. ${ }^{13}$ The massive counterforce attacks of the maximalist school would certainly demonstrate resolve if perceived as limited, but they ; would produce immensely greater casualties than all past wars but one have produced historically. Because of the size of the strikes and the casualties produced, they also are much more likely to be mistaken for a decision to commit muttal suicide by engaging in a countervalue exchange, mather than a decision to demonstrate resolve to fight by holding a 
segment of a nation's indu. trial base at risk. If, for some reason, one wanted to produce as many casualties as produced by a massive counterforce attack, this could be done with much fewer, less capable weapons then the counterforce attack would require.

The likelihood of escalation from 'limited' counterforce attacks makes another assumption of the maximalist school questionable: the assumption that nuclear war can probably be kept limited. No maximalist categorically believes it can, but their arguments suggest that the possibility is at least high. It is possible that a nuclear war would be terminated short of an allout nuclear exchange, but it is also very possible that it would not. No rational leader would esculate to mutually-suicidal countervalue attacks, but leaders may become irrational due to fear or other sources of Clausewitzian friction, or they may act in what would appear to be an irrational manner because of a nuclear 'fog of war'. The numbers of wear.ons necesary for large counterforce strikes (up to thousands) and the immense casualties produced by such strikes are much more likely to be mistaken for a massive countervalue artack than the much smaller limited nuclear attacks in the MAD-plus strategy.

The LNOs of the MAD-plus strategy would demonstrate political resolve vrith much less risk of being mistaken for escalation to countervalue attacks and with much fewer casualites than massive counterforce attacks. The maximalist strategy usually does include small LNOs like those of the MAD-plus strategy, but it is the large counterforce options that are usually emphasized almost to the cxclusion of the smaller options. The maximalist strategy is not criticized here for excluding sinall LNOs but rather for including large ones. The LNOs of the MAD-plus strategy would be on the order of tens of weapons at most. An attack by 7 Poseidon SLBMs and 3 Minuteman III ICBMs could destroy around 73 percent of the former Soviet 
Union's oil refining capacity producing about 1 million prompt fatalities. ${ }^{14}$ A fraction of this small strike force aimed at the refineries farthest from cities could destroy a smaller fraction of Russian oil refining capacity, signaling a capability to destroy the rest of this vital industry but also signaling a willingness to let Russia preserve its industry by prompt cessation of hostilities, all while producing casualties well below the level of total casualties in past major twentieth century wars.

The MAD-plus strategy does not make victory possible, but it provides the positive aspects of the maximalist strategy (assured second strike capability, flexible LNOs to demonstrate resolve and enhance credibility) without the negative aspects (massive casualties from 'limiled' attacks that produce no military benefits, possibility of being mistaken for a massive countervalue attack thus increasing the risk of escalation). The maximalist strategy is based on an attempt to conventionalize nuclear weapons by using them solely on military and leadership targets and thus avoid the jus in bello prohibitions against harming innocent civilians and escalating the conflict to disproportionately destructive levels of violence. The high amount of collateral damage 'at results from the inherently destructive nature of stralegic weapons makes such conventi. .aalization impossible.

The MAD-plus strategy also has the benefit of prescribing cheaper and less threatening force postures. Since the maximalist strategy seeks the maximum survivable counterforce capability allowed by treaty, and in some cases, even a damage limitation capability, the force postures that logically follow from this strategy can casily the mistaken as an attempt to develop a first-strike capability, which is destabilizing. The MAD-plus strategy does not specifically require hard-target-kill capability (though high weapons accuracy is desirable for limiting 
collateral damage from LNOs), and it does not have the open-endsd force requirements of 'seeking the most possible' that the maximalist strategy does, so the MAD-plus deterrent force is unaffectod by fairly broad fluctuations in opponent capability. This in turn leads to cheaper force postures, since the most expensive capabilities of strategic weapons, high cocuracy and maximal survivability, are not in as high demand.

If the MAD-plus strategy is betier than the maximalist strategy, why did both the United States and the Soviet Union follow a maximalist strategy during the Cold War? Nuclear decision makers may not have understood the irrationality of the maximalist strategy. Even if they did, it would still be necessary to adopt the maximalist strategy if it appeared that one's opponent believed in the maximalist strategy. The reason is that deterrence is a subjective thing - what deters is determined in the eyes of the party to be deterred. A maximalist believes that a favorable or at least neutral balance of survivable counterforce capability is neceanry for deterrence. If such a balance does not exist then deterrence does not exist, and the side favored in the counterforce balance will gain political leverage. Is If this is believed, then a MAD-plusprescribed force posture would not provide stable deterrence because it does not ensure a favorabls or neutral survivable counterforce balance. Therefore, a MAD-plus force posture cannot reliably deter a maximalist.

During the Cold War, the doctrine and force postures of both superpowers suggested that they adhered to the maximalist strategy. Both sides engaged in an arms race to deploy more and better hard-target-kill capable weapons. Both sides, even if they preferred the MAD-plus strategy, had to judge from their opponent's force posture and doctrine that there was a significant chance that the opponent was a maximalist. Therefore, the 'reluctant' side had to the 
maximalist as well. This reluctant maximalism is illustrated by Hamld Brown's reports as Secretary of Defense in the late 1970s. Brown pointed out that a nuclear war could not be won and damage could not be limited, which are MAD-plus a ssumptions, but he also pointed out that we had to deter the Soviet Union, and it was not obvious that the Soviets held these beliefs. Therefore, the Uniled States had to adopt a maximalist force posture and doctrine in case the Soviet Union was maximalist."

If this was the case in the past, why can we change to MAD-plus strategies now? What do we need to do? America and Russia, or the CIS, need to admit simultaneously that 'the emperor has no clothes', that the maximalist strategy is objectively flawed, and the reason both sices adhered to it during the Cold War was for fear that the other side believed it and could only be deterred if the first side pretended to believe it as well.

America had genuine fear that it might have to fight the Soviet Union in the Cold War, and inaintained a constant readiness for war, including massive nuclear war, because of this fear. The Soviet Union claimed to have the same fear of America. American performance in the Gulf War suggests that the Soviet Union had good cause to fear our capabilities, if not our intent. The necessity to prepare to fight and the horror of nuclear war lead to the attempt to conventionalize nuclear weapons. Now that the Cold War is over and the 'evil empire' has collapsed, this fear has almost totally disappeared. As long as the fear existed, it was difficult to change from the maximalist strategies adupled because of this mutual fear. As statements by Presidents Bush and Yeltsin suggest, the decline of fear has lead both Anerica and Russia to seck arms reductions." 


\section{What is the Situation Now? The Military Establishments and Academia}

Currently, both the Imerican and former Soviet miliary establishments seem to continue to adhere to the maximalist strategy. Civilians in both states, primarily in the academic community in America and in the Academy of Sciences and Russian Foreign Ministry in the former Soviet Union, are advocating MAD-plus strategies. Traditionally, the executive branches of both governments have accepted military primacy in strategic doctrine, but recently, it has become difficult to tell which strategy, if any, the Bush and Yeltsin administrations adhere to.

THE AMERICAN DEBATE. Throughout the last years of the Cold War, the U.S. Department of Leiense propounded a strategy that was classic maximalism." In lnte 1991, as the Soviet Union dissolved, the commander in chief of the Strategic Air Command (CinCS AC) commissioned a report titled 'The Rule of Nuclear Weapons in the New World Order' known as the 'Reed Report' after the chairman of the committee that produced it. The Reed report called for unilateral reductions of the U.S. strategic arsenal to a level of 5,000 warheads \pm 20 percent." The report specificaily rejeited the adoption of a minimal deterrent considering it 'the least credible of all nuciear postures'. ${ }^{\text {nn }}$ It also specifically called for retention of counterforce targeting." Thus the most recent strategic analysis to come out of DoD is still maximalist.

In the American civilian community, several analyses have recently come out advocating MAD-plus strntegies or at least deterrent postures that are more compatible with a MAD-plus strategy than with a maximalist strategy. Harold Feiveson and Frank von Hippel have produced a plan calling for the deployment of highly survivable strategic forces of about 2,000 warheads to implement a strategy of 'finite deterrence', which includes an assured destruction capability plus small LNOs. ${ }^{n}$ The National Academy of Sciences has released : report calling for U.S. 
reductions to 3,000 to 4,000 strategic warheads on each side and ultimately to 1,000 to 2,000 warheads 'as world conditions improve'. 3 The study exrludes an opponent's strategic nuclear forcss from the target base which is cempatible with a MAD-plus strategy though this strategy is not specifically endorsed. ${ }^{24}$ These are just two examples from a pool of many. ${ }^{25}$

THE RUSSIAN/CIS DEBATE. Soviet nuclear strategy has never been a perfect mirtorimage of American strategy, but in the pre-Gorbachev era, Soviet nuclear-strategic doctrine was reasonably similar to American maximalist doctrine. The classic Soviet work of the 1960s that helped determine the force postures in the 1970s, Marshal Sokolovskiy's Sovier Military Strasegy, considered victory in nuclear war possible and called for targeting all types of targets in America, particularly U.S. nuclear weapons. ${ }^{n}$ In the 1980s, Soviet doctrine was revised under the leartership of Marshall N.V. Ogarkov, but these revizions did not focus on nuclear strategic doctrine. Victory in nuclear war was declared to be impossible, but Sokolovskiy's targeting doctrine was never specifirally rejected. 2

The doctrine of Reasonable Sufficiency put forth as part of former Soviet President Mikhail Gorbachev's policy of New Thinkdng produced a two-camp division in Soviet strategic thought similur to the American dichotomy. The general precepts of Reasonable Sufficiency, or as the Sovia military called it, Defense Sufficiency, are as follows:

1. The primary goal of military doctrine is to deter war, both nuclear and conventional.

2. Military capabilities should be limited to levels capable of stopping aggression only.

3. To deter nuclear war, a situation of mutual assured destruction should be maintained at the lowest possible level of nuclear weapons in the near term, and in the lone term nuclear weapons should be abolished. 
There is substantial debate in the former Soviet Union on precisely what the general precepts mean. Pre-August coup Soviet military officers telieved reasonable sufficiency involved the ability to deliver 'crushing rebuffs' to an aggressor and demonstrated continued concern with numerical nuclear parity. The concem with numerical parity in particular suggests continued adherence to a maximalist strategy concemed with the U.S.-Soviet counterforce balance. Thus, the former Soviet military establishment seems to want to retain the old maximalist strategy but perhaps at lower levels.

The officers who most frequently made policy announcements during the early days of reasonable sufficiency are either no longer alive or in power. ${ }^{30}$ The current leadership, including the last Soviet DCfense Minister Marshal Yevgeny Shaposhnikov, who is now the commander-in. chief of the CIs forces including all strategic forces, has yet to make any substantial statement on strategic doctrine, so it would seem likely that military doctrine has not changed. The current CIS military establishment is expending most of its energy trying to ensure a cecent quality of life for its officers and men.

Since 1987 Soviet civilians in the Academy of Sciences and Foreign Ministry have called for the adoption of a nuclear doctrine similar to the MAD-plus and minimalist strategies." Many of these civilians, and even some junior military officers, have specifically called for the adoption of the 'McNamara Criteria' from the minimalist nuclear strategy." Thus a civilianmilitary strategic dichotomy exists in the CIS that is similar to the civilian-military dichotomy in the United States. 
What is the Situation Now? The June 1992 Joint Undersianding

Russian and American political leaders izave yet to decide between the two strategies. Former President Gorbachev's speeches were never specific enough to tell what doctrine, if any, he adhered to. For example, about the most spexific thing he said was, 'the disarmament process should proceed on an equal footing, on the basis of strict observance of balance at all stages'." There is no real way to tell whether he supported maximalism or minimalism. When still president, he did permit the deploymtnt of highly counterforce-capable 'maximalist' weapons like the SS-24, SS-25, and the SS-18 $\bmod 5$, bu: under his policy of Glasnost, he also permitted civilians like Alexei Arbotov and Yevgeny Primakov to publicly call for a minimalist or MAD-plus strategy.

Only recently has Russian President Boris Yeltsin made any pronounrements on nuclear strategy or force postures. He has said that Russian missiles will no iongar be targeted af American cities." This is a confusing statement, for ai strategies of deterr nce are ultimately based on the threat to destroy an opponent's society or leadership, and it is impossible to do this without destroying large portions of an opponent's population, which is equivalent to targeting cities. So it is likely that President Yeltsin is seeking to present an unthreatening appearance to the United States without fully understanding nuclear strategy. President Bush has not made any pronouncements on American pust-Cold War nuclear strategy to go along with his actions on force posture, so the current nuclear strategies for both superpowers are somewhat ambiguous.

The terms of the June 1992 Joint Understanding on Reductions in Offensive Strategic Arms (which is to be codified in a formal treaty in the near future) suggest that the superpowers 
could be headed loward MAD-plus nuclear strategies, but the evidence is not decisive. Below is a table of the provisions of the Joint Understanding and the two excinanges of proposals that preceded it.

\section{Praident Bush. September. 1991}

(1) All U.S. arntogic bombers lakee off of alert.

(2) All ICBMg to be removed under START immodincaly deactivated.

(3) Reil-gerrien basing program for MX and hend motilo bunchor progum for Midegetmmn cencelled.

(4) SRAM II cancelled.

(5) Continus the B-2 program and SDI.

(6) Sock elimiantion of MIR Vod ICBMs.

\section{Prexident Burh, Innuary 1992}

(1) B-2 protuction beltad a 20 planes.

(2) Midgetman ICBM program cencellod.

(3) Production of 475 te W88 wathead for the Trident II SLBM haltod.

(4) Procuremeal of the advaced cruise missile inlted.

(5) Production of the MX ICBM haltod.

(6) Fully fund SDI.

(7) If CIS aprees to eliminate MIRVad ICBMs:

\section{Provident Gorbicher October 199}

(1) All atratogic bombers taken oft of alert.

(2) 503 ICBMs immediately deactivated.

(3) Research on Soviex SRAMs ceared.

(4) All mobile mimeiles to stay in garrieons.

(5) Stratogic Wabeads cul fmm 6,000 required by START to 5,000 .

(6) Production of SS-24 ceased.

(7) Call for U.S.-Soviat angotistions to reduce arsenals by ono half.

\section{Presiden Yelusin. Ienuer 192}

(1) 1,250 stratogic warboade do-alerted.

(2) Six eubmerinee to be atripped of leuachers.

(3) Production of Bens and Blechject bombers helled.

(4) Moex START lovels in 3 yours inatead of 7.

(5) Joint U.S.-Ruesien dofense should replece SDI.

(6) U.S. and Russis should cul anenals to 2,000 to 2,500 wartheade.

(1) Eliminale MX.

(2) DeMIRV Minutemen III.

(3) Reduce SLBM wartead by a third.

(4) Coavert a large autraber of atrntogic bombirit to cosveational uso.

\section{Lune 1922 Joins Understending}

Ptene I (n bo echioved within soven-year START timo fremo)

(1) Pach side will have a maximum of 3,800 to 4,250 tolal integic warheads.

(2) A maximum of 1,200 MIR Vod ICBM warheads.

(3) A maximum of 650 wartieads on heavy ICBMs.

(4) A maximum of 2,160 SLBM warheade.

(5) Strntegic bombern to bo counted as carrying the actual number of warteads thoy are equiped to carry. 
Phise II (to ba achioved by the year 2003)

(1) A maximam of 3,000 to 3,500 total strategic warteads.

(2) All MIRVed ICBMs must be eliminated.

(3) A maximum of 1,750 SLBM warheads.

(4) All misailes encept the SS-18 may be downloaded.

(5) Levels to be achieved by the year 2000 if sufficient U.S. nid for weapons destruction is forthcoming.

On the American side, many of President Bush's actions, particularly the January unilateral measures and proposals, are compatible with an intent to adopt a MAD-plus strategy. The halt in MX production, cancellation of the Midgetman ICBM program, and the January offer to scrap the MX and deMiRV the Minuteman III all represent a retreat from counterforce targeting and preoccupation with the counterforce balance. According to Pentagon spokesman Pete Williams, the United States will indeed scrap the MX and deMIRV the Minuteman In when the Joint Understanding is codified in 'START I'. ${ }^{35}$ ICBMs have traditionally been the backbone of both American and Soviet hard-target-kill capability, and these reductions will reduce American counterforce capability below what would be required by the simple numerical cuts required under 'START II'.

The cancellation of the W88 warhead is also an action inconsistent with a maximalist preoccupation with counterforce capability. The Trident II will still have some hard-target-kill capability, but not nearly as much as it would have with the W88. ${ }^{36}$ The cancellations of the SRAM II and ACM similarly reduce U.S. counterforce capability beyond what is required by numerical cuts. The systems were intended to enhance the penetrability and hard-target-kill capability of strategic bombers on a second-strike mission. The proposal to halt B-2 production after five more planes are built could also be a retreat from maximalism, since one of the Air 
Force's main rationales for the plane was to use it to track down mobile Soviet ICBMs in a nuclear war.

President Bush's actions do not all lean towards the adoption of MAD-plus force postures. The United States was successful in getting a ban on MIRVed ICBMs included in the Joint Understanding. This ban will require the elimination of the traditional backbone of the Soviet/Russian strategic arsenal, MIRVed ICBMs, particularly the SS-18 heavy ICBM. ${ }^{37}$ Elimination of the Soviet/Russian advantage in MIRVed ICBMs has been a U.S. arms control goal since SS-17s, 18s, and 19s were deployed shortly after SALT I was signed, and this goal is indicative of a maximalist desire to have as favorable a counterforce balance as possible. To achieve this long-term maximaliıt goal, the United States only had to give up a portion of its traditional strategic stronghold, SLBMs.

The President's proposals could also be interpreted as an attempt to hang on to the B-2 bomber, which is the bomber that thaximalists prefer most. In the September proposals, the President sought to retain the B-2 program. The change in the January proposals could reflect a genuine belief that the reduced threat no longer requires the bomber, or it could represent a continued attempt to salvage the program, since building a total of twenty planes instead of halting production at the 15 planes that are currently complete or under production will require ieeping the B-2 assembly line open til: the next century. 31 The President may be hoping to be able to resurroct the program in the future.

There are also some ambiguities in the U.S. position. Taking American bombers off of alert greatly reduces the survivability of American land-based forces in the event of a surprise attack. Formerly synergy between alert bombers and ICBMs ensured that either one or the other 
would survive any preemptive attack, since no Sovier attack was capable of targeting both simultaneously." With American bombers off of alert, both bombers and ICBMs can be attacked by Russian ICBMs. The only programs that could preserve land-based weapon survivability were the MX rail garrison basing and Midgetman hard, mobile launcher programs, both of which were cancelled. Thus overall American strategic survivability has been greatly reduced, though not catastruphically. The United States fears a loss of control over nuclear weapons in the CIS, so American bombers may have been taken off of alert to allow the CIS to reciprocate reducing the likelihood :- in unauthorized or accidental launch of CIS strategic bombers.

The reduction in surpinse-attack :esiliency could represent a retreat from concern with the counterforce balance. To deter a surprise attack, the United States would be relying solely on its strategic submarine force, and would have much less survivable counterforce capability than it would have if land-bascod survivability were maintained with alert bombers 0 : mobile ICBMs. The reduction in surprise attack resiliency could also represent continued adherence to the maximalist strategy coupled with a belief that, in the post-Cold War world, the likelihood of a surprise attack in so small that it is practically negligible. This is probably a good assumption, but if the Soviet Union had become benign enough for the United States to almost ignore the possibility of surprise attack, it would seim illogical to plan to continue to spend tens of billions of dollars on the B-2 bomber, which the administration planned to retain at the time hombers were taken off of alert.

Some of the Bush proposals could suggest a desire to adopt a MAD-plus force posture in the future, but there is no definitive evidence that maximalism has been rejected. In 
testimony before the Sennte Foreign Relations Committee, Secretary of Defense Dick Cheney Idescribed the reasoning behind the September 1991 proposals and behind the U.S. position on the Joint Understanding. A change in strategy was not listed among the rationales.

The President's September 27 initiative had several specific goals: to reduce the nuclear threat to the United States and our allies; to reduce instability, especially the instability posed by MIRVed ICBMs; to reduce the financial burden of the military forces of both sides; and to encourage those in the Soviet Union who were working to enact political, economic, and military reforms and to facilitate their efforts.

The Joint Understanding reflects our best judgement as to what strategic forces tha United States requires to maintain an effective deterrent. The requiremetns are far leas than they were deemed necessary in the past and reflect our recognition of the changing world. Our analysis took account of the break-up of the Soviet Union, its reduced capabilities to project conventional power, and the further reductions in military potential promised by this agreement. ${ }^{\infty}$

It may be that the President is seeking to open the door to a mutual U.S.-Russian change in nuclear strategies without taking the dangerous, unstable step of doing so unilaterally. If this is the case, the President is 'doing the right thing', but there are also severnl alternative explanations for the President's proposals. As previously mentioned, some of the proposals may be an attempt to increase control over nuclear weapons in the CIS. If the United States takes wexpons off of alert, like the strategic bombers, Russia and the CIS can do so too. Non-alert weapons ze much less likely to be accidentally launched or launched without authorization. The Bush proposals could also represent continued pursuit of the traditional U.S. arms control goals of limiting Soviet/CIS MIRVed ICBMs, the weapons which represent the greatest threat to the United States. Another possible motive for U.S. behavior is an attempt to 'lock in' quickly deep cuts in strategic weaponry without a change ir Joctrine in case the CIS reverts to a hostile government. It is also possible, though, that these measures were proposed solely in response 
to fiscal pressures minimally informed by strategic reasoning and produced by public euphoria over the end of the Cold War.

A final possible explanation for U.S. acceptance of less counterforce capability is a decline in the target base. Leadership bunkers in the non-Russian republics will no longer need to be targeted in some scenarios, there will be much fewer silos in the former Soviet Union (perhaps as few as 300 or less under Phase II of the Joint Understanding), and there will be much fewer mobile ICBMs for bombers to cahse down. Also, since Soviet air defenses are no longer being modemized and are proabably deteriorating, bomber penetrability is much more certain than the Pentagon expected it to be in the 1990s if the Soviet Union still existed.

Like the American position, the Soviet/Russian position has some provisions that are compatible with a MAD-plus strategy. Perhaps the most surprising aspect of the Ruscian position is the open acceptance of counterforce inferiority vis a vis the United States. When the Joint Understanding is implemented, there will be a range of total strategic warheads allowed to either side. In a not-for-attribution briefing, senior U.S. administration officials stated that the United States would retnin the higher level of warheads allowed under each phase of the Joint Understanding $(4,250$ and 3,500), and the Russians would retain the lower levels $(3,800$ and 3,000)." The U.S. administration may not be an infallible predictor of Russian incent, but there would be no need to include the lower total warhead levels in the treaty if the Russians intendad to retain the sume, higher numbers that the United States will retain. Both S.ILT II and START called for precise numerical strategic parity.

Russian acceptance of numerical disparity is not as new os it may scem at first glance however. The United States and the Soviet Union never had the same number of strategic 
warheads in the past. SALT II required parity in launchers, not warheads, and START required parity in a combination of launchers and warheads, but there were special warhead counting rules for bomber weapons that permit a disparity in numbers of real as opposed to counted warheads. What is new under the Joint Understanding is that Russia is admitting that it will not have precise parity with the United States. Acceptance of numerical disparity is undesirable to a maximalist, so open acceptance of disparity would suggest a Russian tilt towards the MADplus or minimalist strategy. But since the acceptance of disparity is only a change in appearances and not reality, the open acceptance of disparity cannot be considered conclusive evidence of a Russian shift i.i strategy.

Russian/CIS cancellations are even more likely to be purely budget-driven than American reductions, considering the state of collapse in the CIS economy, so Russian cancellations cannot be construed as incontrovertible evidence that a change in strategy has taken place. Under the Joint Understanding, Russia is free to build up to the allowed levels by replacing old MIRVed ICBMs with new single-warhead ICBMs, or by retaining more than just its newest SLBMs, but statements by U.S. officials and the inclusion of warhead ranges in the text of the agreement suggest that these options will not be pursued. It is likely that these options will not be pursued because of their expense. The current Russian budget is said to provide almost no funds for new hardware.

It is also not certain that Russia can reduce its inventory of warheads as fast as Mr. Yelesin has offered. The head of the Russian nuclear weapuns industry has stated that Russia will need American monetary aid to reduce its arsenal within ten years to the levels proposed 
by Mr. Yeltsin in January. ${ }^{3}$ Fast achievement of Phase II of the Joint Understanding is contingent upon U.S. financial aid to Russia.

Without the Joint Understanding, the Yeltsin and Gorbechev proposals taken alone could have been interpretted as still supporting a masimalist strategy, so the Joint Understanding came as a bit of a surprise. During his February 1992 visit to the United States, Yeltsin declared Bush's January proposals 'lopsided'. In a speech delivered to senior Russian military officers in the week preceding the June summit, Yeltsin declared that the United States was seeking unilateral advantage over Russia in calling for a MIRVed ICBM ban and implied that he would not accept such terms." Apparently, the MIRV ban was resisted up to the day before the Joint Understanding was signed. Resistance to a MIRV ban would be compatiable with a maximalist negotiating position. However, during the summit, Yeltsin gave in on an issue that a Rusaian maximlist with a strategic force heavily dependent on MIRVed ICBMs would never be expected to give in on.

The warhead levels in the Joint Understanding could reflect ei ir nuclear strategy. Maximalists are concemed primarily with the counterforce balance, so a specific warhead level alone cunnot necessarily be construed as reflecting a particular strategy. However, maximalists require enough weapons to ...set the McNamara criteria and cover a target base including un opponent's stntegic forces and leadership, and it may be difficult to meet these requirements at the low level of arms in the Joint Understaniding.

Analysis of the Russian position on the Joint Understanding suggest that it is very possible that President Yeltsin would like to adopt a MAD-plus or minimallst nuclear strategy, though the evidence is not conclusive. It will require more concise public statements of dectrine 
than either President Bush or President Yeltsin have made so far to demonstrate clear evidence of an intent to try to change strategies by either side. President Bush or his successor has the authority and power to change American stratagy. President Yeltsin, however, may not be the final arbiter of Russian nuclear strategv Perhaps the important question to ask on the Russian side, though, is not what does Mr. Yeltsin think, but what does the former Soviet military think. This will be discussed below.

\section{What Has Changed? Why Should Strategies Change Too?}

Unlike superpower strategic doctrines, superpower threat perceptions are changing, and this is what is permitting arsenals to change without doctrine changing. It is this change in threat perception that allows the United States to halt B-2 production, cancel the Midgetman program, and scrap the MX. These weapon systems were all designed for nuclear war fighting. The superpowers no longer expect to have to fight a nuclear war or to have to be prepared to fight a nuclear war in order to deter the other side, $s 0$ it is believed that war fighting weapons can be safely abandoned. One might argue that fiscal pressures are driving force reductions, and this is certainly a major factor. But both the United States and the Soviet Union were in difficult economic situations before the end of the Cold War, and fiscal pressures were not producing such drastic cuts then. It is the change in the threat that has permitted fiscal pressures to have much more influence over force structure planning. Change in threat perception can be thought of as the fundamental cause of the force reductions or as a permissive condition, and fiscal pressures can be thought of as the proximate cause. 
During the Cold War, the United States, at least the U.S. defense establishment, saw the Soviet Union as an implacable threat to U.S. interests and bent on world domination." This threat and adherence to the maximalist nuclear strategy drove the requirement for highly counterforce-capable weapons. In the words of General John Chain, former commander-in-chief of the Strategic Air Command,

We need systems with improved accuracy and a better capability to penetrate advanced defenses and strike hardened targets. Weapons with prompt hard-target capability are essential to disrupt Soviet attack plans as quickly as possible. It is imperative that we develop the capability to detoct and attack the growing Soviet mobile target set. Additionally, we must have other forces sufficiently durable and flexible to hold remaining targets at risk throughout a nuclear conflict in order to control escalation, prevent coercion, and convince the Soviets to end the conflict. ${ }^{\infty}$

This argument was specifically used to endorse the MX missile, both silo and nil-based, and the B-2 bomber.

With the end of the Cold War, the Department of Defense no longer considers a conflict with the former Soviet Union likely. As Secretary of Defense Dick Cheney testiffed to Congress,

It is improbable that a global conventional chalienge to U.S. and Westem security will emerge from the Eurasian heartiund any time in the neas future. Even if some new leadership in Moscow were to try to recover its lost empire in Central Europe and to threaien NATO ... then the reduction of its military, conventional capabilities over the past several years would make the chances for success remole without a prolonged period for force generation and redeployment."

Chairman of the Joint Chiefs of Staff Colin Powell, CIA Director Robert Gates, and Defense Intelligence Agericy Director $\mathrm{L}$. Gen. James Clapper have all made similar statements." Since the need for escalation dominance in the event conventional hostilities arose drove the maximalist strategy, it can be assumad that the defense cstablishment sees the nuclear as well as the 
conventional threat to be greatly reduced. The American defense establishment does not consider the Russian/CIS threat to be non-existent. Rohert Gates testified that unrest in the CIS is still the most serious potential threat to U.S. security." Powell and Cheney similarly point out that the former Soviet arsenal, particularly the nuclear arsenal, still poses a significant though greatly reduced threat to the United States. ${ }^{\text {so }}$

if the presence of a massive immediate threat drove the requirements for weapons like the MX and the B-2, then the decline of the threat is driving the cancellation of these weapons. For example, a Department of Defense press release issued the day President Bush announced a cap on B-2 production at 20 aircraft states,

With the transformation of the Soviet threat, America's strategic bomber force is less likely to face the sophisticated air defenses for which the B-2 is designed. The current strategic force of B-1Bs and B-52s can be adapted to ensure adequate capubilities for strategic nuclear and conventional missions."

The ambiguity on nuclear strategy implied by tile substance of President Bush's propusals suggests that a reduced perception of the threat and not a change of nuclear strategy is driving reductions.

The transformation in threat perception in the CIS is similar to the one in the United States. It is debatable how threatened the Soviet Union used to feel. Sokolovskiy's Soviet Military Strasegy and later doctrinal statemetns in the Ogarkov era state in no uncertain terms that the Soviels viewed the United States as an immediate major threat to their security. ${ }^{32}$ Many Americans may find it incredible that the Soviets really felt America had malevolent intentions loward them, but American performance in the Gulf War suggests that the Soviets had reasun to fear at least American capabiiitics if not A merican intent. It was certainly reasunable fror the 
Soviets to believe they would be challenged by the United States in any area of the g!obe where they tried to expand their influence.

With the end of the Cold War, the former Soviets changed their perception of the threat similar to the way Americans have done. During his trip to Washington in February, 1992, President Yeltsin stated, 'From now on, we do not consider ourselves to be potential nemies, as it had been previously in oui doctrine'. 33 CIS Commander-in-Chief Shaposhnikov has similarly stated, 'As to potential enemies, we simply do not have them. Our doctrine might be described as an all round defense'. In In justifying his abandonment of parity to Komsomolskaya Prarda after the June Summit, Yeltsin said, 'But we know one thing: We [Russia and the U.S.] will not fight each other'. ss Again, as is the case with American defense planners, the former Soviet military does not believe that there is no threat from the United States, just that the American threat is reduced. $\%$

It is difficult to prove that Soviet or Russian threat perceptions drive weapons procurement, since procurement decisions are rarely discussed in the Soviet or Russian/CIS press. But the Soviet force structure of the 1970 s and 1980 s is very compatible with the doctrine and threat perception of that era, so some correlation between threat perception, doctrine, and force structure probably exists. Since threat perception has changed but doctrine remains ambiguous, it is likeiy that the change in threat perception is what is driving CIS/Russian force posture changes.

If threat perceptions are changing and producing changes in force postures that make strategic arsenals less threatening, why does it matter if the superpowers change to the MAD. plus stmiegy or stick with the old maximalist strategy'? There are several reasons why a change 
in strategy is still important. One is that the rejection of the maximalist, war-fighting strategy will be conducive to continued cordial U.S.-Russian/CIS relations. Past Soviet and American war plans and force postures have been based in part on an analysis of the other side's strategic doctrine." If one's opponent publicly adheres to a war-fighting doctrine, it is not unreasonable to assume he or she might be planning on fighting a war. If the less-threatening MAD-plus strategy is publicly adopted, it is more difficult to believe that one's opponent is still planning on fighting a nuclear war, which is in turn conducive to peaceful relations. As long as the Cold War strategies remain in place, prudent decision makers in both states should be less inclined to think that the Cold War is completely over.

A second reason the MAD-plus strategy should be adopled is that this strategy calls for cheaper force postures. Highly-survivable counterforce capability that maximaliste deaire is expensive. The MAD-plus strategy requires much less survivability and hard-target-kill capability than the maximalist strategy and so can be impiemented with much cheaper force postures. The United States has halted almost all strategic modernization, but it has not totally rejected counterforce modemization. The accuracy of the Minuteman III ICBM will be upgraded. The CIS was still building SS-18, $\bmod 5$ and SS-25 ICBMs and developing new SLBMs before the Joint Understanding was signed." Such continued developinent and deployment is only necessary if more of the hard-target-kill capability of the SS-18 and more of the survivability of the SS-25 is desired.

A third reason the MAD-plus strategy should be adopted is to avoid a return to the arms race if democracy in Russia and the CIS fails and the Cold War refurns. The maximalist strategy leads to arms races because of the quest for counterforce superiority, which requires 
constant attempts to deploy more or at least 'better' weapons as an opponent does the same thing. The quality of a MAD-plus deterrent force is unchanged by fairly large fluctuations in an opponent's capability, so a change in one side's capabilitiss is unlikely to lead to an actionreaction arms race if MAD-plus strategies are adopted.

One might ask, 'If we retum to the Cold War, won't both sides revert to the maximalist strategy anyway?' This is possible, but the maximalist strategy is illogical, and if both sides admit it is illogicin and adopt MAD-plus strategies, it will be difficult to revert to the old strategy. It may be difficult to admit in the first place that the 'emperor has no clothes', but once everyone has admitted it, it is difficult to go back to pretending that a naked emperor is fully clothed.

A final reason to change strategies, is that a change to the MAD-plus strategy will increase strategic stability. If forces are cui and the old maximalist strategy is retained, the United States and Russia could end up with forces that are incapable of meeting the doctrine's requirements for stable deterrence. Security would thus depend on continued good will. If this good will evaporates, the situation could be very unstable if either side has a force that it thinks is unable to deter the other. As previously stated, many of the cuts announced by Presidents Bush and Yeltsin are not compatible with the old maximalist strategy, $s c .4$ strategies do not change, it is possible that neither side will have a socure deterrent according to its own doctrine.

What Must Happen for MAD-Plus Straregies to be Adopted?

Civilian leaders on both sides must give strategic policy to their military establishments rather than take it, as has been done in the past. This will probably be casier to do in the United 
States than in the former Soviet Union. President Bush or his successor can decide that America will adopt a MAD-plus strategy and then give it to the Pentagon to be implemented. There may be some, even extensive, bureaucratic resistance, but strong presidential effort, particularly from 2 Republican president who was Ronald Reagan's vice president, should be able to overcome bureaucratic resistance in the Pentagon.

It is uncertain how much control the new CIS leaders have over their military establishments. It is unlikely that non-Russian leaders have much control at all over the former Soviet military. In December, Russian forces in Kazakhstan test-fired an SS-19 ICBM, probably configured to test its suitability as a space-launch vehicle, from a military base in Kazakhstan to the Kamchatka peninsula. Kazakh officials were unaware of the test until queried by the United States. ${ }^{\infty}$ Under the CIS agreement for a unified nuclear command, only the Russian President Boris Yeltsin has actual physical control of former Soviet weapons, though this control is to be exercised in consultation with the leaders of the other three former republics with nuclear weapons on their soil."1

ad is tis

It remins to be seen how muct control President Yeltsin has over the former-Soviet military, and the Joint Understanding has not been well received by all of the top officers in the former Soviet military. At the press conference following the signing of the Joint Declaration, Yeltsin stated that Russian Defense Minister Pavel Grachev had approved of the agreement before it was signed, and Grachev has since come out in support of the agreement. ${ }^{62}$ However, Grachev does not have control over any strategic nuclear weapons, CIS Commander-in-Chief Shaposhnikov does, and Shaposhnikov has boen critical of the treaty. In the Russian press, Shaposhnikov has described the agreement as being an agreement of intent for the time being; 
he has stated that there is no alternative to parity; and he has stated that it is up to the military to finalize the agreement. ${ }^{63}$

If the former Soviet military decides to resist the treaty, it is likely to do so indirectly through foot-dragging on mplimenitation rather than by open revolt, though forceful measures cannot be completely ruled out. Military resistance to the treaty will not be without civilian support. There is a large conservative contingent in the Russian parliament, and parliament must ratify the new treaty just like the U.S. Senate must ratify it on the American side. An example of Russian conservative opinion on the treaty is as follows.

An insane step has been taken toward our self-destruction and unconditional switch to the prolection of the U.S. nuclear umbrella, since the destruction of our land-based strategic missiles is nothing but the complete abandonment of an independent state policy and total surrender. ${ }^{\text {ss }}$

Yeltsin does have some leverage over the military. It seems that currently the primary institutional interest of the military is the social welfare of its officers and men, and Yeltsin is addressing this concem. During the disolution crisis, Yeltsin got the support of the Soviet military because Russia could pay them, and Gorbachev's Soviet government could not." Shortly before the summit, Yeltsin signed a decree giving all Russian servicemen an 80 percent pay increase, the second raise in as many months. ${ }^{67}$ If Yeltsin can successfully address these military ir'erests, then perhaps he can produce a change in doctrine. The fact that Yeltsin's renunciation of parity in numbers of strategic warheads is a change in appearance and not in fact may also help him gain military approval for the new agreement.

How Will We Know Things Have Changed? 
The firat indicator of change will be a change in tziaratory strategic policy. Public statements alone are not positive proof of intent because they could reflect 'grandstanding' for public consumption or disinformation to lull an opponent into complacency. Hov ever, if leadership really does undergo a change of intent and wants to encourage reciprocity, then it would probably make a public declaration of its change. A concrete change in declaratory policy is, therefore, a necessary but not sufficient indicator of a change in strategy.

The second indicator of change will be change in deployments. Statesmen may not always act on what they say, but they generally act on what they believe; therefore, a combination of declaratory policy change and changes in force deployments compatible with the new doctrine will be sufficient indicators of change. Changes in force deployments alone are not enough, because both sides must change strategies simultaneously for the change to be stable. A reactive combination of mutual declarations followed by force posture alterations will be necessary for each side to know that the other is on the path of change.

One of the specific technical indicators that MAD-plus force postures are replacing maximalist force postures is that counterforce capability decline faster than warhead counts. Scrapping highly hard-target-kill capable weapons first, like the MX, SS-18, and SS-24 ICBMs deployed with ten warheads each, is the way to do this. Another indicator is that marginal imbalances in survivable counterforce capability not impede reductions so long as each side can; maintain an assured second strike capability after a few weapons for use in LNOs are subtracted from its strategic force.

Many of the unilateral actions and some of the provisions of the Joint Understanding match the indicators stated above. Changes in force postures alone are not enough, though. As 
stated above, changes in force posture without changes in doctrine can lead to dangerous instabilities if conflict returns and one or both superpowers discover they have cut their arsenals to the point of not having a secure deterrent according to the doctrines they adhere to. A combination of changes in force posture and changes in declaratory doctrine is the best indicator that a change in doctrine has occurred. So far, only changes in force posture have occured, some of which provide ambiguous evidence of the strategy behind them, and these changes could be driven purely by changes in threat perception and by fiscal pressures. As of now, if cannot be determined if a change in strategy has occured.

\section{What About the Future of the CIS?}

The future of the former Soviet Union is highly uncertain. A reasonable question to ask is how would unification of the former republics, total collapse of the CIS, or the rise to power of a 'Russian Napoleon' or a 'Russian Hitler' affect the benefits of adopting the MAD-plus strategy?

There are thiee likely possible future states of unity for the former Sovict Union: there could be a true union like the old union with one central authority, a semi-unified commonwealth of mostly-sovereign states like the CIS, or up to 15 complstely separate states no more unified than the Unitod States and Canada are unified. In the event that there is a retum to a strong union, the U.S.- union relationship would be bilateral as it was in the past, so traditional bilateral deterrence theory would still apply. If the CIS breaks up into completely separate states, then the United States will still only have to deal with one superpower. Russia alone would still be a nuclear superpower, but none of the other republics, even if they chose to retain their current 
nuclear weapons, would be superpowers. The Ukraine, at current levels, would have 1,656 strategic warheads, Kazakhstan 1,410, and Belarus 72 compared to Russia's roughly 7,700 strategic warheads. Only strategic weapons and a few tactical weapons in Belarus now remain outside of Russia, and these weapons should be transferred to Russia by the end of the decade according to a protocol signed in Lisbon by the four nuclear republics and the United States." It is thus likely that Russia will be the only nuclear-armed former Soviet republic in a few years. If the other republics decide to renige on the Lisbon Protocol in the future, they will have even fewer weapons than they have now and will be unable to credibly claim any nuclear stratrgy but a minimalist or MAD-plus strategy.

The in-between case, in which the CIS continues to exist as is, would also lead to a continuation of a bilateral strategic relationship in the future. Either all the members would act in unison, similar to a new union for strategic purposes, or, on the other extreme, unity would totally break down resembling the case of 15 different states discisssed above. Thus, the future state of unity among the former members of the Soviet Union will not change the strategic relationship between the United States and the successor to the Soviet Union.

There are two ways that the strategic nuclear relationship could cease to be bilateral, neither of which are likely. The first is that Russia could completely unilaterally disarm, which, given its proximity to nuclear-armed China, is unlikely regardless of how unthreatening they consider the United States to be. The second is that both America anc Russia could disarm to a point of equality with Britain, France, and China. This second possibility is also unlikely since neither Russia nor America are likely to be willing to accept nuclear equality to China. The few analyses that mention a quintalateral relationship usually expect the current third nuclear 
powers to disarm proportionally to the superpowers thus retaining a situation of Russo-American nuclear superiority. ${ }^{70}$ If Russis and America did choose to accept parity with the other nuclear powers, then only a MAD-plus strategy would make sense, because no one power could maintain the favorable counterforce balance that maximalists desire against more than one other power and certainly not against all four.

Another important possibility to consider is that a Russian 'Napoleon' or even a 'Hitler' might arise. This is not necessarily likely, but it cannot be discounted. Gotbachev tried to solve the Soviet Union's problems, and if Yeltsin and some follow-on leader also fail, there could be a rise of fascism in Eurasia. The case of interwar Germany suggests that there is some correlation between economic difficulty and the rise of fascism. " Preoident Yeltsin himself likes to point out this possibility. ${ }^{n}$ He may be trying to scare the West into providing Russin with more economic aid, but the possibility of a return to a hostile dictatorship is still real.

If such a leader arcse and became hostile to the West, it would be hard to make a maximalist strategy credible again once both sides had already agreed that 'the Emperor has no clothes' and the MAD-plus strategy is objectively more correct than the maximalist strategy. Even if a fascist leader did make a reversion to maxisnallsm credible, and the Uniled States had to similarly revert, it is likely that the U.S. could rebuild a maximalist strategic posture much more quickly than Russia could, given the current relative state of Westem and Eastem economies. If a fascist leader arose who was completely crazy, he or she could not be deterred by any strategy. In this unlikely but possible event, the best that America could have done before hand would be to get both American and Russian arsenals as small as possible so such 
a leader might not be able to destroy the world. Adopting a MAD-plus strategy now is the best way to do this.

\section{Conclusions}

The United States and Russia should adopt MAD-plus deterrent strategies in the postCold War ern: The benefits of adopting this strategy will be increased strategic stability if a future crisis occurs, enhanced political cordiality between America and Russia as mutual fear is further reduced and arsenals become less threatening, and a maximized peace dividend. If such a strategy is adopted by hoth states, it will be more difficult to retum to the days of the objecti:ely irrational maximalist strategy and the accompanying large, expensive, counter-forcocapable force postures that go with it.

America and Russia (or the CIS) must adopt the MAD-plus strategy simultareously, because the MAD-plus strategy, while objectively more reasonable than the maximalist strategy, may not be a credible deterrent to an opponent who still believes the maximalist precepts. Whether or not this simultaneous transition can be achieved depends on the ability of American and Russian civilian leaders to convince their military establishments that it is safe to change. This will be more difficult to accomplish in Russia than in the Unitod States.

So far, a change of strategy has not taken rlace. Many aspocts of the reciprocal unilateral reductions and the June Joint Understanding could be interpreted as suggesting a desire to move toward MAD-plus strategies, but these actions alone cannot be reliable indicators or producers of change. The Sepiember and January proposals and the Joint Understanding are being driven by changes in threat perception and fiscal pressures that could lead to a dangerous 
situation if threat perceptions revert to Cold War norms because of the rise of a Russian or CIS government houtile to the West. Neither leader has yet to make a firm policy statement that such a shift should occur, and until such a policy statement is made, neither leader can be sure the other is willing to make the change away from the old Cold War deterrent strategies. But the reciprocal unilateral reductions and the Joint Understanding could be good first steps if the intent is indeed to lead to a change in superpower strategy leading to maximized peace dividends and a more stable world order. 


\section{Notes}

'McGeorge Bundy, 'The Bishope and the Bomb', New Yort Roviow of Boaks, June 16, 1982, pp. 3-6.

${ }^{2}$ For a discunsion of the McNamera Criterie no Alain C. Enthoven and K. Wayno Smith, How Much is Enough? Shaping the Dofinse Program, 1961-1960 (Now Yort: Heper and Row, 1971), Pp. 207-210.

The formule EMT = $Y^{2 n}$ given the equivaleat mogatonange of a wertead where $Y$ is the yield of the wartead in MI. This is a measuro of tho area of land a wathead can cover with lachl offects. As an oxample, 138 wo 276 Minutemen IIIMk12As with 3-335 kt wartoends each would carry 200 to 400 EMT.

"For wome claseric antemeots of the maximaliat delerrent atrelogy, no Herold Brown, DoD Annual Raporr. FY 1982 (DC: U.S. DoD, OSD, 1/19/81), Colin S. Gny and Keilh Payao, 'Victory lo Pouiblo', Forrign Polligy no. 39 (Summer 80), pp. 19-22, Colin S. Gray, 'Nuclear Stracegy: A Cen for a Thoory of Viclory', Invomatlonal'

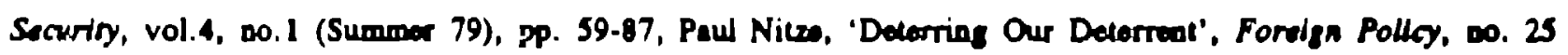
(Winter 76-77), pp. 195-210, and Paul Nitzo, 'Aesuring Stralogic Stability in en Bra of Doteats', Forrign AFairn, vol.54, Do.2 (Jan. 76), pp. 207.232. My deacription of the strutogy in not a paraphanen of any oos of then statomeate but a logically consiateat conglomeration of their arguments into one cobereat atrategy.

'Not ali maximalias omphasize this ansumption. Colin Gray and Kaith Payao (op. cit.) do emphenizo thie

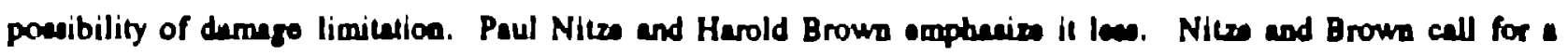

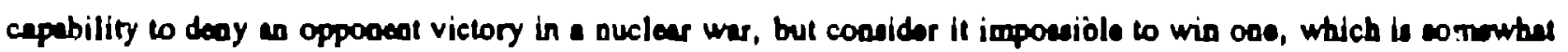
embigrous on wholber of not damage can bo meaningfully limitod.

'Better' meane s paition where the relative number of counterforce-cepable weapone alter or exchenge is more fevorable to the attecker than it wes bofore the exchange.

'Deainond Ball, 'Development of the SIOP, 1960.83', in Siraiegic Nuclear Targering. Pp. 57-83, Deemond Ball and Joffroy Richoleno, ats. (Ithece: Comell, 1986), p. 81.

'For an excellent diecuesion and criticiom of the conventionalization of nuclear wapons see Jervia, op. cll.

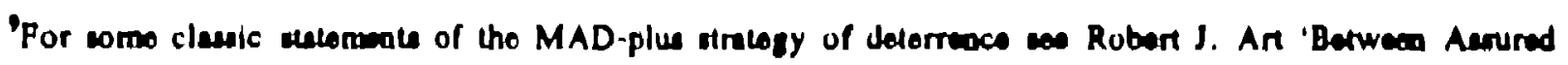


Deatruction and Nactear Victory: The Caso for the 'MAD-Plus' Poaturs', Eshics do. 95 (April 88), pp. 497-516, McGeorge Buody, Georse P. Keanan, Robert S. McNamarn, add Gererd Smith, 'Nuclear Weapons and the Allantic Allience', Foreign Afairs vol,60, Do.4 (Spring 1982), Pp. 753-768. Robart Jorvis, The Mbogic of American Nuclear Straregy (Ithecs: Cornoll, 1924). Thomes Scholling, Ams and Infuencr (Now Heven, CN: Yalo Univertity Press,

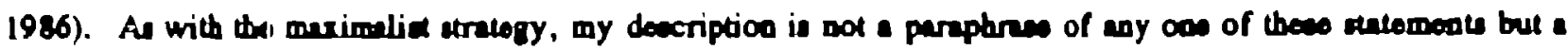
logically conainteal conglomeration of their argumeots into a cobereat atratery. Robert Art sbould be crediced for the nermo 'MAD-plus'.

${ }^{10}$ Schelling, Chs 283.

"U.S. Congreas, OTA, The Effects of Nuclear War (Washington, D.C.: US OTA, 1979), Pp. 12-18.

${ }^{12}$ Williem H. Dougherty, Barben O. Lovi, and Frank N. von Hippel, 'The Coneoquencess of Lmiled Nuclear Attecke on the Uniled Stalea'. Invernasional Security, vol. 10, no.4 (Spring 1986): 5, and 'Civilien Casualtien from Limiled Nuclear Allecks on the Soviet Union', Insermasional Serurity, vol, 12, no.4 (Winter 87/88), p. 169.

IScholling, Che. 2203.

${ }^{14}$ OTA, p. 13.

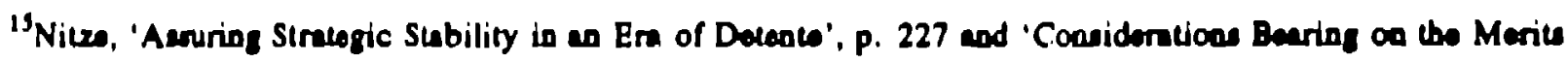
of the SALT II Agroment es Signed at Vienne', in Alering Amorica, d. Charles Tyruler, II (DC: Porgumon a Braesy's, 1989), pp. 196-7.

16 Brown, pp. 38-40.

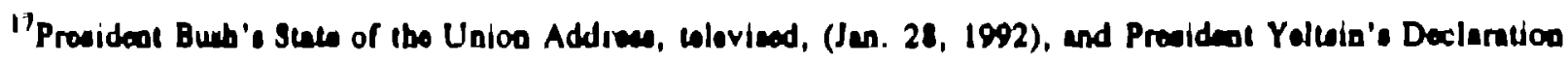

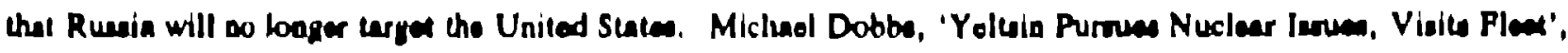
Washingion Past (Jas. 29, 1992), p. A23.

"Compare Harold Brown's Deparment of Defonse Annual Repor FY 1982, op cil., pp. 3-19, 32-44, with Casper Wointorger, Anvual Report to the Congress FY Iese (DC, U.S. Oovernment Printing Office, Jan. 1, 1982), Pp 42-72, 94-56 and Prank C. Carlucei, Annunl Repor to Congress Fros (U, S. Oovomment Prineing Ofnco, Pab. 11, 1988), pp. 25-77, s0-5s. 
1"Thomen C. Rad and Miched O. Wheoler, The Role of Nuckear Weapons in the Now World Order, Dec. 1991, releaned for pub. 1/8/92, p. 29.

200id., p. 28.

${ }^{21}$ Ibid. , p. 26.

${ }^{2}$ Harold A. Feivenos and Frank N. von Hippol, 'Beyond START', Intemailonal Securlsy, vol.1S, no.1. (Summor 1990), pp. 115-158.

${ }^{\mathrm{D}}$ National Acedomy of Sciences, The Fure of the U.S. Sovies Nuclear Relatlonship, Wahington, D.C.: National Academy Preas, 1991), p. 3.

24 Mid., p. 28.

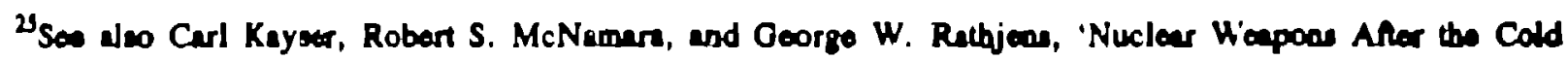
War', Foraign Afairs, vol. 70 (Fall 1990), pp. 95-110.

Whith the poasible exception of some of the militery writings during the 1980s, the Sovied Union nover had a decleratory doctrine aimiler to the American dnctrios of flexible ropons, which involved auclear warfighting a

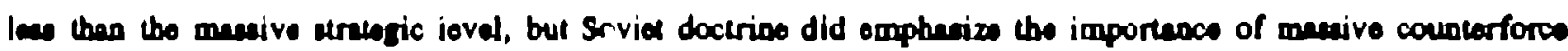

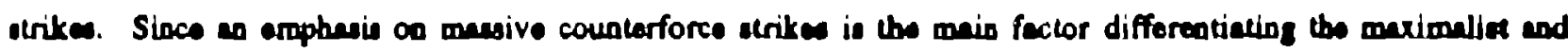

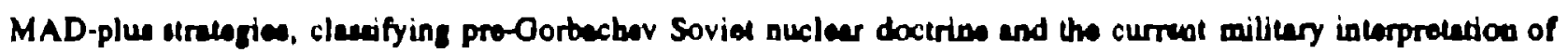

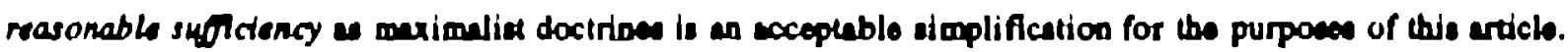

nV.D. Sokolovakiy, Sovia Military Straregy, Jnd w. trenslated by Hentet Feat Scott (Now Yort; Cran, Rusack, 1975), Pp. 127-211.

"See Mery C. Filegerdd, 'Maribal Ogarkov on the Modora Throal Operation', Naval War College Rovtew, vol. 34, no.4 (Autumn 1986), pp. 16-25, Leon Gouro and Micheol J. Deano, 'The Sovial Strateric Viow: Ogartov on Tolal Victory' and 'Updating Sokolovakiv', Strasegic Reviow, vol.13, no.4 (Fall 1985), Pp. 92-106, and Jama M. McConnell, 'Shine in Sovied Viow's on the Proper Focue of Militury Dovelopment', World Politics, vol.37, no.3 (April 1985), pp. 317-393. 
7D. T. Yarov, 'The Military Doctrine of the Wanaw Pect is the Doctrine of the Defense of Peace and Socialism', Fonden Droadcas Informalon Sorves, Dalby Report, Sova Unlon (FBIS-SOV), (July 27, 1982), p BB2, 'Repont by D. T. Yarov (at the 28th CPSU Congreas, July 1990)' Cumbas Digest of the Sovid Press, vol.97, no. 29 (Aug. 22, 1990), p. S, Marahal S. P. Akhromoyov, '1 ho Doctrine of Proventing War, Dofeading Peace and Socialiom', FBIS-SOV-88-001 (Jan. 4, 1988), p. 42.

30Def. Min. Yazov participated in the coup and is awaiting trial, Manhal Akhromeyev, who was Gorbechov's pernonel miliery atvisor, committed suicide. Former Chief of Staff Mulinoveliy hes deo been repleced.

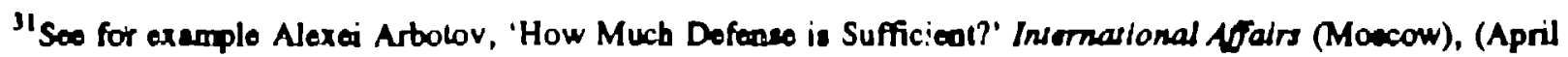
1989), pp. 31 44, Yovgeny Primakov, 'Now Philosophy of Poreign Policy', FBIS-SOV (July 14, 1982), pp. CCS10, and Viuly Zhurtin, Sorgai Karaganov, and Andrei Kornunov, 'Reaconable Sufficiency or How w Breat the Vicious Circb', Now Thmes (Moscow) vol,40, wo.82 (Oc1. 12, 1987), pp. 13-15.

${ }^{32}$ Arbolov, p. 36, Primukov, p. 618, Zhurtin, Kanganov, and Kortunov, p. 7, and Col. V. Strabtor, 'From tho Sundpoint of the Now Thinking: Militery Party Yautorday and Todey', FBIS-SOV-89-002 (Jen. 4, 1989), p. 2.

${ }^{33}$ M. S. Oorbacbov, 'Crow a Walerabed in the Country's Hiatory in a Fitting Manner', (ppeach in tho Odaces militery diatrict, Aug. 17, 1990), Currens Digest of the Sovin Press, vol. 42, no.32 (Sept. 19, 1990 ), p. 7.

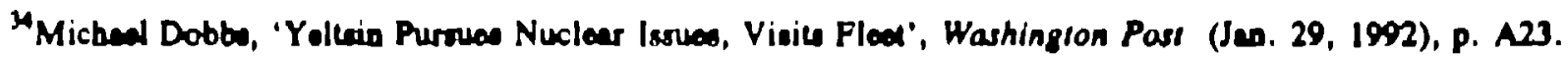

${ }^{33}$ Poto Williem, Defens Department Regular Briefing. Thuraday, June 18, 1992.

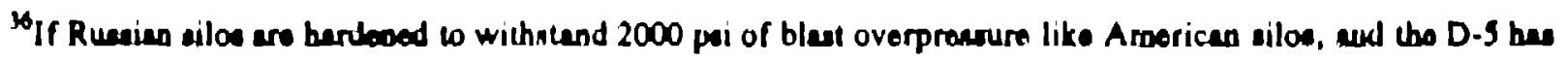
a CEP of $120 \mathrm{~m}$, replecing the $475 \mathrm{kt} W 88$ wathend with the $100 \mathrm{kt}$ W76 will reduce the D-5e ainglo-ahor kill probability from abous 99 porcent to 76 percant (sunuming perfoct reliability). If Russien wilos are berdar, ay herdened to withaland 5000 pai, the single-shot kill pinbability drope from 85 percont to 54 percent.

${ }^{17}$ The Joint Underatending doee not explicitly mquire SS-18, to be eliminalod, but the Pliwe II ban on MIRVad ICBM: combined with the explicil ben on downlonding the 10-worhend S5-18 will requiro olimination of this misuile. 
${ }^{30}$ Paricin A. Olimate, 'USAP Budget Plen Preserves F-22, C-17 But Cepe Steallh Bomber Production', Aviation Weat and Space Techrology (Feb. 3, 1992), p. 23.

"For an expleantion of the synergistic relationship, 100 Breal Scoworoft, Committes Chnirmen, Report of the Presidens's Commlesion on Strasegic Forces, (Weshington, D.C.: U.S. Government Printing Office, 1983 ), p. 17.

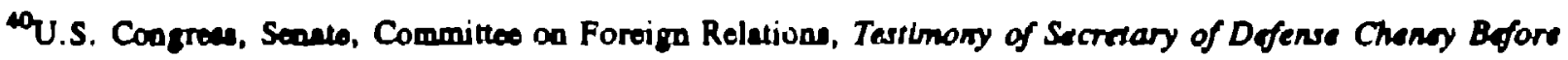
the Senare Forvign Relatione Commirree on the Straregic Anns Reduction Theary. June 26, 1992, pp. 3, 8.

${ }^{41}$ Reuter Tranecript, White House Background Briefing, Iune 16, 1992.

${ }^{42}$ Pred Hintt, 'Mocow Slabea Miliury Sponding', Washingron Past (Jun. 25, 1992).

${ }^{43}$ Fred Hiatt, 'A-Amo Chief Says Ruenis Needs Help', Washingron Past (Fob. 5, 1992).

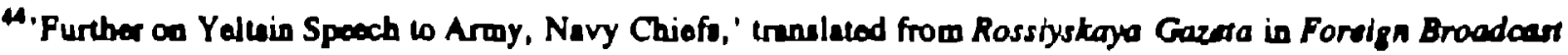
Informasion Sarico Dally Report an Censtal Asia (PBIS-SOV-92-114), Jupe 12, 1992, p. 38.

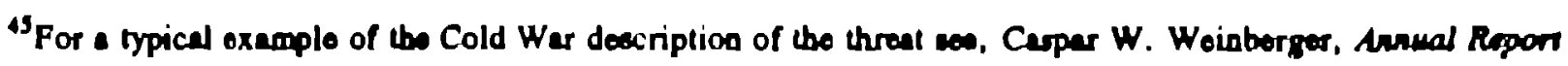
to the Congress, FY 1988, U.S. Departmeat of Defease, Jenuny, 1987, pp. 23-25.

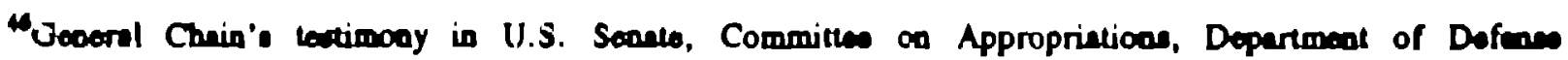
Appropriation for PY 1988. 100th coos., lat vese, p. 161.

${ }^{7}$ U.S. Senele, Budgut Committeo, proliminery tranecript of the FY 1993 Dofean Budget Hearinge, Pob. 3, 1992, p. 15.

"Colin L. Pows", Natlond Miliary Sirusegy 1992, Department of Defoneo, Jan. 1992, pp. 2, 3, 16. Diructor Cales' and Diractor Clepper's ceatimony is highlighled in Oeorgo Lardner, Jr, , Republica' Procurement of Arme Said to Plunge', Washingron Past (Jan. 23, 1992).

"Bill Gertz 'Oales: CIS Inutability Biggeat Throal', Washingron Thmes (Fob, 26, 1992).

${ }^{30}$ Seo eleo Thome Read and Micheol Whecler, The Ri le of Nuclear Weapons in the Now World Order, U,S. Department of Defence, Jenuery, 1992, pp. 6.9. 


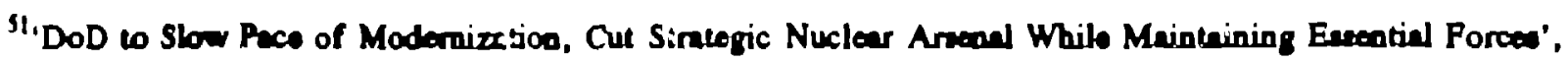

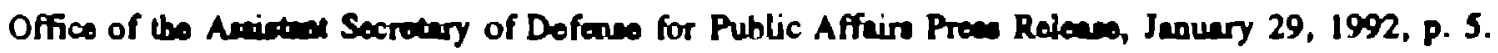

${ }^{32}$ Seo for axample, Sotolovitiy, pp. 52-69, and Leon Gouro and Micheal J. Deano, 'Ogarkov on Toual Victory' [Excerpte from History Teaches Vigilance, Moncow, 1985] Strategic Rowlow, vol.13, no.4 (Fall 1985), p. 97.

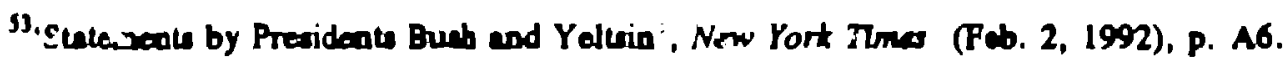

Motho Loyd, 'Militury Chuof Says CIS Hes No Finemiea', Financial Tmes (Fob. S, 1992).

95. Yoluin on "Moving Awny From Puity"', translated from Komsomolskaya Prouda in FBIS-SOV-92-119, Juno 19. 1992, p. 23.

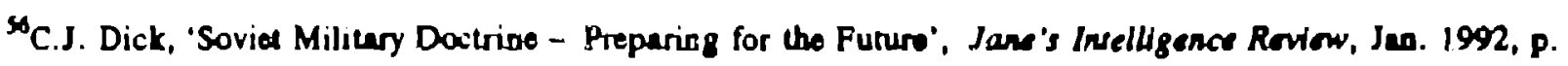
35 .

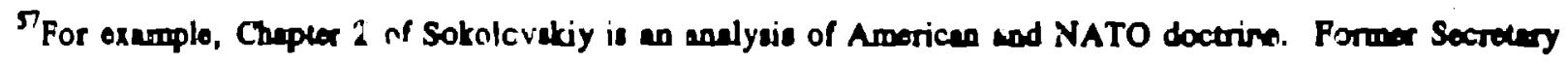
of Dofenes Herold Brown referted io Scrviet doctrine in his developmeat of the countervailing arategy. Sen, for oxamplo, the D.D Anounl Report for ficcai year 1982 (DoD, Jan., 19, 1981, p. 38). The Department of Dofoane

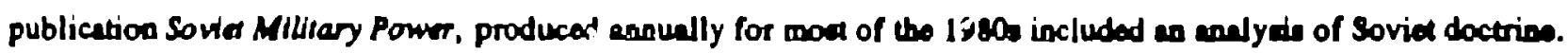

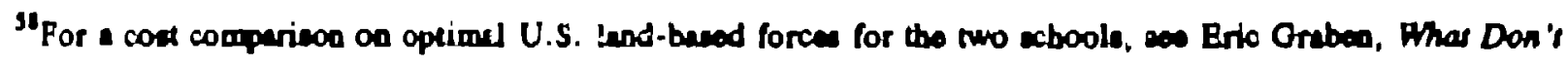
We Need Anymore?. (Lenham, MD: Unive aity Preas of Americe, forbcomidot).

Mertz.

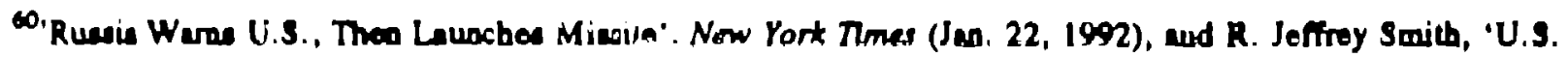

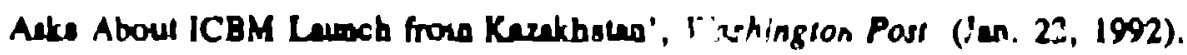

"Acoording to Marabel Yovgeny Shaposhniknv, Commander-in-Chiof of the CIS and former Suvia Dofenes

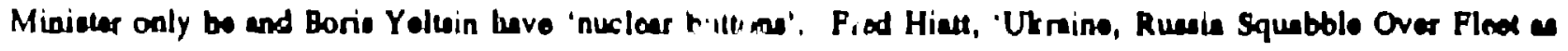
Tansions Orow', Washinglon Pass (Jan, 9, 92).

61' Excorpes from Bumb-Yolein Conference: Working Toward a Safor World, 'Now York Mmes, Juoe 17, 1992, and 'Oracher on Arme Cuts,' PBIS-SOV-92-12n June 22, 1992, p. 15 . 
13 Shapahnitor Apen Arme Control Agreemenl, FBIS-SOV-92-122, June 24, 1992, p. 2.

This is the opinion of Alexi Artalov, director of the Mocoow-based Cenles for Arme Control and Stralegic

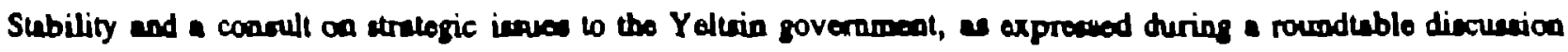
hosted by the Center for National Security Studies at Los Alemoe National Laboratory.

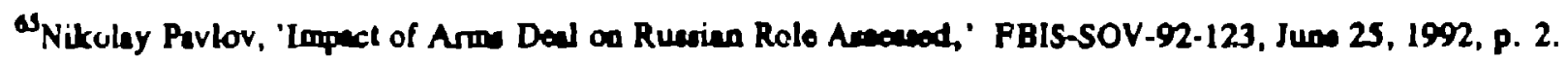
Pavlov is \& Russien Fedention people's doputy, a member of parliement.

Patrick E. Tyler, 'U.S. Concerned that as the Union Breaks Up, So Does the Soviet Military', Now York Timas, (Dex. 10, 1991): A19, and Serge Schmimen, 'Gorbacher is Ready to Reaign as Poat-Sovien Plen Advicor', Now York Thmes, (Dec. 13, 1991), A1, 22.

"Yaltrin Discunes Reform Policien, U.S. Trip', tranlated from an inlerviow on the Moscow Runaien Television Networt, in FBIS-SOV-92-114, June 11, 1992, p. 31.

Moho D. Moraceo, 'Sovien Militery Breakdown Worriea U.S. As Control Over Nuclear Arme Splinterr', Avlation Weak and Space Tectinology, (Dec. 16, 1991), p. 20, and Incermational Institule for Stratogic Studien, The Military Balancs, 1990-91, (London: Brewey's, 1990), p. 34.

"Don Oberdorfor, '3 Ex-Sovia Stutes to Give up A-Arms', Washingrun Past (Mey 2! 1992). The protocol ano laid out the provision by which the four former republice would abide by tho START traty.

${ }^{20}$ Feiveson and von Hippel, (op. cit., p. lio) envivion Americe and Rurie with aboul 2000 watheads and the third nucleas powere with 200-500 watheads each. Keyeer, McNemern, and Rethjens, op. cil, almilerly expect the third auclear powere to bo willing to accept conlinued inferiority, p. 100.

${ }^{71}$ Tto Ned perty received 2.6 parceal of the popules voto in May 1918. In Sept. 1930 tboy became the recond lergout party in the Reichitug geting 10.3 perceol of the vale. In 1933, when Hillor becamo Chencellor, thoy won on a plurality of 43.9 , wercent of the popular vote.

Twilliam Drozdiat, 'Yolusin Soes Threal of Now Diclaturahip', Washingron Post (Fob. 1, 1992). 